\title{
Prototipe Smart door lock Menggunakan Motor Stepper Berbasis IoT (Internet of Things)
}

\author{
Noer Soedjarwanto ${ }^{1}$, Gigih Forda $\mathrm{Nama}^{2}$,Rega Astu Nugroho ${ }^{3}$ \\ Jurusan Teknik Elektro Universitas Lampung, Bandar Lampung \\ Jl. Prof. Sumantri Brojonegoro No. 1 Bandar Lampung 35145 \\ gigiheeng.unila.ac.id² \\ regaastu8996@gmail. $\mathrm{com}^{3}$
}

\begin{abstract}
Abstrak - Internet of things adalah sebuah konsep yang bertujuan untuk memperluas manfaat dari konektivitas internet yang tersambung secara terus menerus . adapun kemampuan nya seperti berbagi data maupun sebagai remote control dan lain sebagainya. Maka dari itu penulis berinisiatif untuk membuat pengaman sekaligus pengontrol pintu dari jarak jauh untuk mempermudah pemilik rumah mengontrol keadaan kunci saat terbuka maupun sedang terkunci.Aplikasi di rancang menggunakan mit inventor dengan berbagai vitur diantaranya tombol untuk membuka kunci dan menutup kunci dengan mengatur sudut dan arah gerak motor menggunakan driver motor steeper. kemudian pada aplikasi menampilkan notifikasi kondisi pintu saat di jalankan ,dan juga menampilkan berapa arus dan tegangan yang di gunakan saat menjalankan alat tersebut. Hasil penelitian memperlihatkan bahwa semakin berat beban yang diberikan pada alat ini maka nilai daya saat membuka dan mengunci pintu tetap konstan. Prototype smart dor lock menampilkan data secara realtime dan hanya diberikan beban $0,08 \mathrm{~kg}, 0,115 \mathrm{~kg}$, dan $0,170 \mathrm{~kg}$.
\end{abstract}

Kata kunci - smart door lock, Motor Stepper, internet of things, Driver Motor Stepper

Abstract - Internet of things is a concept that aims to expand the benefits of internet connectivity that is connected continuously. as for its capabilities such as sharing data or as a remote control and so on. Therefore, the author took the initiative to make a security as well as controlling the door remotely to make it easier for home owners to control the state of the lock when it is open or is locked.The application is designed to use a mit inventor with various features including a button to unlock and close the lock by adjusting the angle and direction of the motor using a steeper motor driver. then the application displays a notification of the door condition when it is run, and also displays how much current and voltage is used when running the tool. The results show that the heavier the load given to this tool, the power value when opening and locking the door remains constant. The smart dor lock prototype displays realtime data and is only given a load of $0.08 \mathrm{~kg}$, $0.115 \mathrm{~kg}$, and $0.170 \mathrm{~kg}$.

Keywords - smart door lock, Stepper Motor, internet of things, Stepper Motor Driver.

\section{PENDAHULUAN}

Pada masa sekarang ini segala sesuatunya serba efisien dan praktis. Dirumah dengan kunci konvensional akan tidak efisien jika memiliki pintu yang banyak, karena kita harus membawa banyak kunci. Untuk mempermudah mobilitas manusia, pengembangan teknologi dilakukan seperti penggunaan android sebagai pengganti kunci pintu rumah.Berdasarkan hal tersebut di atas, terpikirkan oleh penulis untuk membuat pengaman pintu yang dapat dikendalikan dari jarak jauh sehingga dapat memudahkan pemilik rumah untuk mengontrol kunci pintu ketika lupa mengunci atau menaruh kunci pintu.

Pada saat ini perkembangan teknologi seluler telah mengalami kemajuan yang sangat cepat. Hal ini ditunjukkan oleh munculnya bermacam-macam jenis ponsel pintar atau sering disebut dengan smartphone. Ponsel pintar saat ini telah menyajikan teknologiteknologi yang dapat memberikan kemudahan bagi para penggunanya. Dari segi operating sistem, ponsel pintar saat ini telah banyak jenisnya seperti android, windows 8, ios dan masih banyak lagi.

Penelitian bertujuan untuk memberikan kemudahan dalam pengoperasian suatu peralatan, perlu juga dipikirkan bagaimana sebuah peralatan dapat dioperasikan secara lebih luas dan fleksibel. Dengan tingginya mobilitas dari si pengguna, sebuah peralatan dituntut untuk dapat digunakan lebih mudah. Disinilah pemanfaatan fitur komunikasi tanpa kabel yaitu internet of things. 
Dengan menggunakan komunikasi internet of things ini pengendalian operasi motor dc jenis stepper ini dapat lebih luas. Maka dibuatlah Prototipe Smart Lock Menggunakan Motor Stepper Berbasis IoT (Internet Of Things).

\section{TINJAUAN PUSTAKA}

\section{A. Internet of Things}

Internet of Things adalah suatu konsep yang bertujuan untuk memanfaatkan teknologi internet yang terus berkembang agar dapat diimplementasikan ke dalam benda fisik sehingga manusia dapat berinteraksi langsung dengan benda tersebut seperti mengirim data dan melakukan kendali jarak jauh secara realtime. Makna lain serupa, internet of things (IoT) adalah sebuah konsep di mana suatu objek yang memiliki kemampuan untuk mentransfer data melalui jaringan internet tanpa melakukan interaksi manusia ke manusia atau manusia ke komputer. Teknologi perangkat keras IoT yang digunakan pada umumnya adalah teknologi radio frequency identification (RFID), wireless sensor network (WSN), dan nano teknologi. Perangkat keras umum seperti kamera dan sensor api, sensor asap, sensor gas atau sensor suhu digunakan untuk IoT. Beberapa teknologi perangkat lunak adalah pemrosesan informasi dan teknologi kemanan. IoT memiliki arsitektur yang terdiri atas perception layer, network layer, dan application layer.[1]

\section{B. Node $M C U$}

Node MCU merupakan sebuah open source platform IoT dan pengembangan kit yang menggunakan bahasa pemrograman Lua untuk membantu dalam membuat prototype produk IoT atau bisa dengan memakai sketch dengan adruino IDE. Pengembangan kit ini didasarkan pada modul ESP8266, yang mengintegrasikan GPIO, PWM (pulse width modulation), IIC, 1-Wire dan ADC (analog to digital converter) semua dalam satu board. NodeMCU berukuran panjang $4.83 \mathrm{~cm}$, lebar $2.54 \mathrm{~cm}$, dan berat 7 gram. Board ini sudah dilengkapi dengan fitur WiFi dan Firmware yang bersifat opensource. [2]

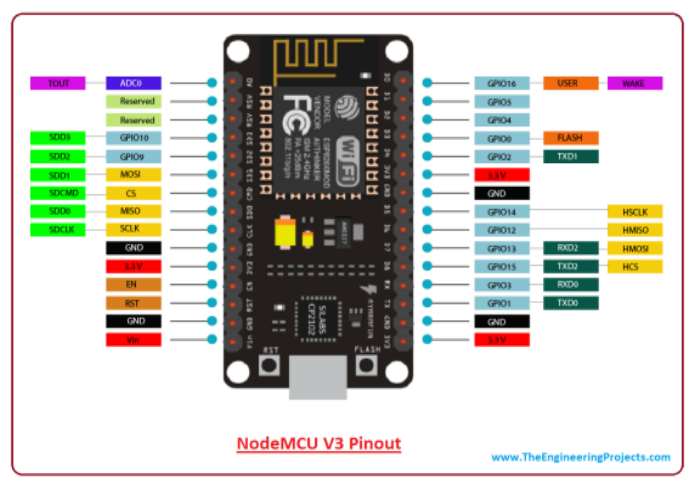

Gbr. 1 Node MCU[2]

\section{Motor Stepper}

Motor stepper adalah perangkat elektromekanis yang bekerja dengan mengubah pulsa elektronis menjadi gerakan mekanis diskrit. Motor stepper bergerak berdasarkan urutan pulsa yang diberikan kepada motor. Karena itu, untuk menggerakkan motor stepper diperlukan pengendali motor stepper yang membangkitkan pulsa-pulsa periodik. Penggunaan motor stepper memiliki beberapa keunggulan dibandingkan dengan penggunaan motor DC biasa.

Pada dasaranya terdapat 3 tipe motor stepper yaitu:

1. Motor stepper tipe variable reluctance (VR) Motor stepper jenis ini telah lama ada dan merupakan jenis motor yang secara struktural paling mudah untuk dipahami. Motor ini terdiri atas sebuah rotor besi lunak dengan beberapa gerigi dan sebuah lilitan stator. Ketika lilitan stator diberi energi dengan arus DC, kutub-kutubnya menjadi termagnetasi. Perputaran terjadi ketika gigi-gigi rotor tertarik oleh kutubkutub stator.

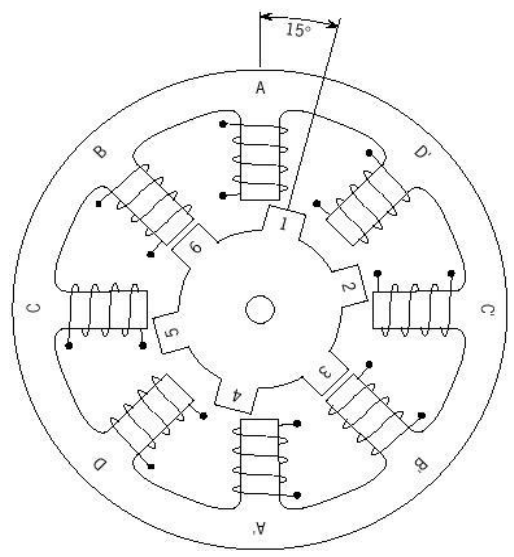

Gbr. 2 Penampang melintang dari motor stepper tipe variable reluctance (VR)[3] 
2. Motor stepper tipe Permanen Magnet (PM) Motor stepper jenis ini memiliki rotor yang berbentuk seperti kaleng bundar (tincan) yang terdiri atas lapisan magnet permanen yang diselangseling dengan kutubyang berlawanan (perhatikan gambar 3). Dengan adanya magnet permanen,maka intensitas fluks magnet dalam motor ini akan meningkat sehingga dapat menghasilkan torsi yang lebih besar. Motor jenis ini biasanya memiliki resolusi langkah (step) yang rendah yaitu antara 7,50 hingga 150 per langkah atau 48 hingga 24 langkah setiap putarannya.[3]

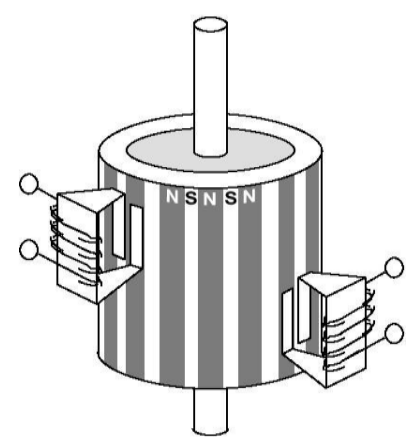

Gbr. 1 Ilustrasi sederhana dari motor stepper tipe permanen magnet (PM) [3]

3. Motor stepper tipe Hybrid (HB) Motor stepper tipe hybrid memiliki struktur yang merupakan kombinasi dari kedua tipe motor stepper sebelumnya. Motor stepper tipe hybrid memiliki gigi-gigi seperti pada motor tipe VR dan juga memiliki magnet permanen yang tersusun secara aksial pada batang porosnya seperti motor tipe PM. Motor tipe ini paling banyak digunkan dalam berbagai aplikasi karena kinerja lebih baik. Motor tipe hybrid dapat menghasilkan resolusi langkah yang tinggi yaitu antara 3,60 hingga 0,90 per langkah atau 100-400 langkah setiap putarannya.

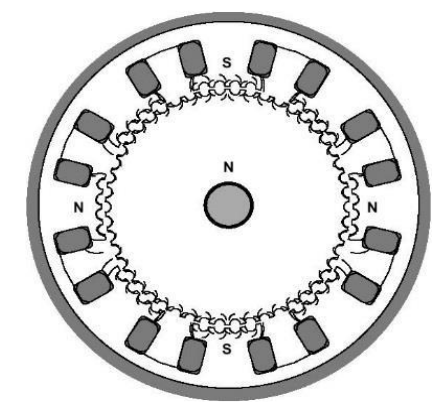

Gbr. 2 Penampang melintang dari motor stepper tipe hybrid[3]

\section{Driver Motor L29N}

L298N adalah komponen elektronik yang dipergunakan untuk mengontrol arah putaran motor DC. Satu buah L298 bisa dipergunakan untuk mengontrol dua buah motor DC. Selain bisa dipergunakan untuk mengontrol arah putaran motor DC, L298 ini pun bisa dipergunakan sebagai driver motor Stepper bipolar. IC driver L298 memiliki kemampuan menggerakkan motor DC sampai arus 2A dan tegangan maksimum 40 volt DC untuk satu kanalnya. Pin enable A dan B untuk mengendalikan jalan atau kecepatan motor, pin input 1 sampai 4 digunakan untuk mengendalikan arah putaran. Pin output pada IC L298 13 dihubungkan kemotor DC yang sebelumnya melalui dioda yang disusun secara H-bridge. Pengaturan kecepatan motor digunakan teknik PWM (pulse width modulation) yang dimasukan dari mikrokontroler melalui pin Enable. PWM untuk kecepatan rotasi yang bervariasi level highnya. [4]. Berikut ini adalah ilustrasi struktur motor stepper sederhana dan pulsa yang dibutuhkan untuk menggerakkannya:
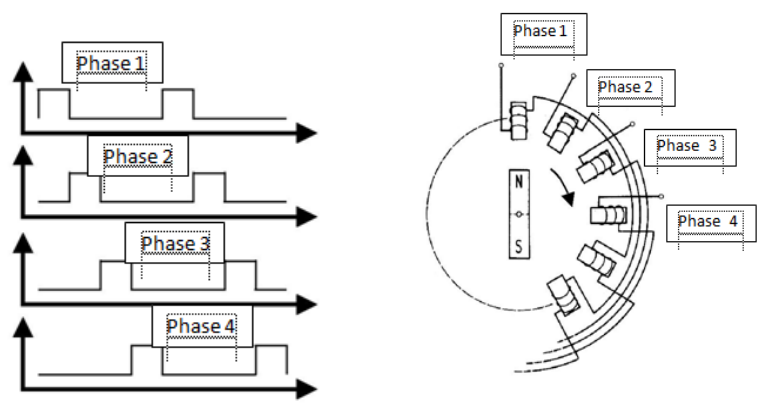

Gbr. 5 (a) bentuk pulsa keluaran dari pengendali motor stepper (b) penerapan pulsa pengendali pada motor stepper dan arah putaran yang bersesuaian[4]

\section{E. Motor Servo}

Motor servo adalah motor yang mampu bekerja dua arah yaitu searah jarum jam atau clock wise $(\mathrm{CW})$ dan berlawanan arah jarum jam atau counter clock wise (CCW) dimana arah dan sudut pergerakan rotornya dapat dikendalikan. Dengan memberikan variasi lebar pulsa atau duty cycle sinyal PWM pada bagian pin kontrolnya. Motor servo dikendalikan oleh sebuah pulsa selebar \pm 20 $\mathrm{ms}$, dimana lebar pulsa antara $0,5 \mathrm{~ms}$ dan $2 \mathrm{~ms}$ menyatakan akhir dari range sudut 
maksimum. Apabila motor servo diberikan pulsa dengan besar $1.5 \mathrm{~ms}$ mencapai gerakan $90^{\circ}$, maka bila kita berikan pulsa kurang dari $1.5 \mathrm{~ms}$ maka posisi mendekati $0^{\circ}$ dan bila kita berikan pulsa lebih dari $1.5 \mathrm{~ms}$ maka posisi mendekati $180^{\circ}$.

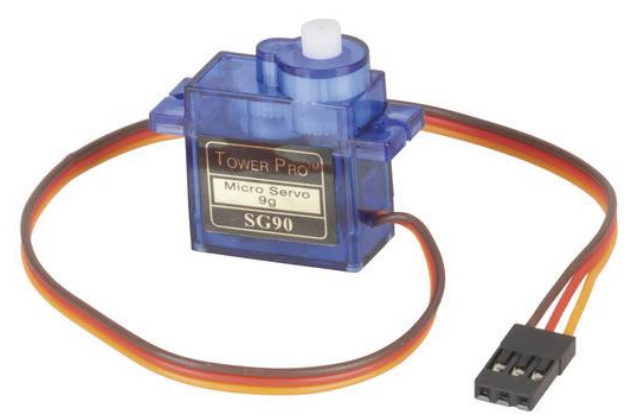

Gbr. 6 Motor Servo SG90

\section{F. Arduino IDE}

Arduino IDE (Integrated Development Environment) merupakan sebuah software aplikasi bawaan dari Arduino yang berguna untuk perancangan, membuat, membuka, dan mengedit sketch dalam Arduino. Sketch merupakan skript program (source code) yang berisi logika dan algoritma yang akan di unggah ke dalam IC Arduino. Di bawah ini adalah tampilan awal software Arduino IDE

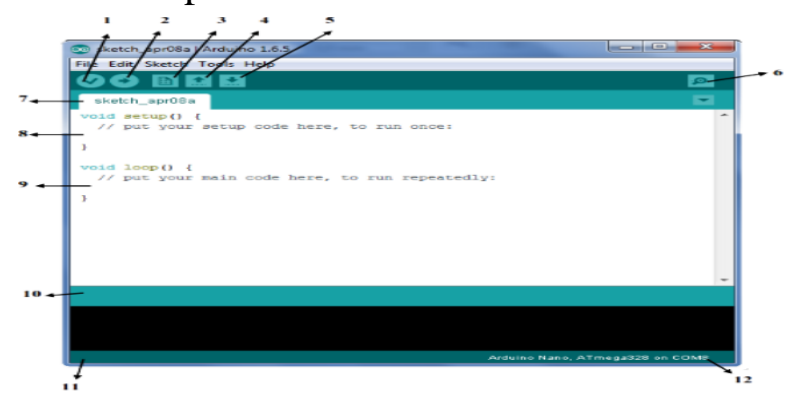

Gbr.7 Softwere Arduino IDE

\section{G. Modul Sensor Ina 219}

INA219 merupakan modul sensor yang dapat memonitoring tegangan dan arus pada suatu rangkaian listrik. INA 219 didukung dengan interface I2C atau SMBUSCOMPATIBLE dimana peralatan ini mampu memonitoring tegangan shunt dan suplai tegangan bus, dengan konversi program times dan filtering. INA 219 memiliki sebuah amplifier input maksimum adalah $\pm 320 \mathrm{mV}$ ini berarti dapat mengukur arus hingga $\pm 3,2 \mathrm{~A}$. Dengan internal data 12 bit ADC, resulusi pada kisaran 3.2A adalah $0,8 \mathrm{~mA}$. Dengan gain internal yang ditetapkan pada minimum div8, maks saat ini adalah $\pm 400 \mathrm{~mA}$ dan resolusi $0,1 \mathrm{~mA}$. INA 219 mengidentifikasi tegangan shunt pada bus $0-26 \mathrm{~V}$ [5]

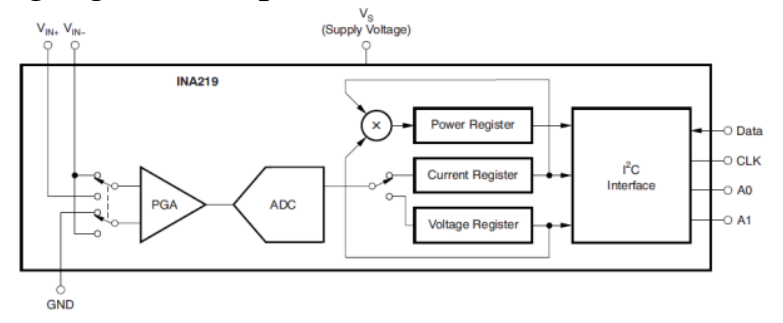

Gbr.8 Skematik sensor Ina 219

Dalam Gbr. 1 skematik INA 219 memiliki Pin I/O data, clock, analog 0 , analog 1 , Vin + , Vin -, ground, dan suplai tegangan. Berikut gambar yang menjelaskan pin I/O dari INA.

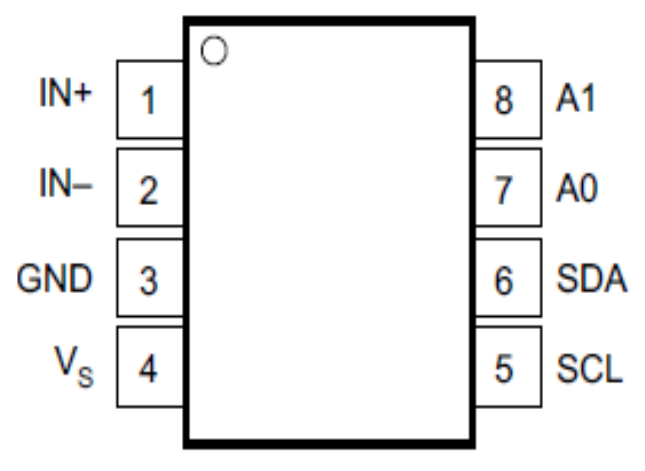

Gbr. 9 Konvigurasi sensor Ina 219

\section{METODE PENELITIAN}

\section{A. Alat dan Bahan}

Dalam melaksanakan penilitian ini alat yang digunakan antara lain:

1. Komputer (PC)

2. Solder

3. Timah

4. PCB board

5. Multimeter

6. Bor PCB

7. Kabel

8. Cairan Feritclorite

Selain alat-alat diatas, penulis juga menggunakan komponen-komponen utama yaitu:

1. Motor stepper Sunchor Nema 17

2. Driver motor stepper L298N

3. NodeMCU

4. Motor servo

5. Gear motor stepper

6. Prototype Kunci pintu Bergerigi 


\section{B. Diagram Alir Penelitian}

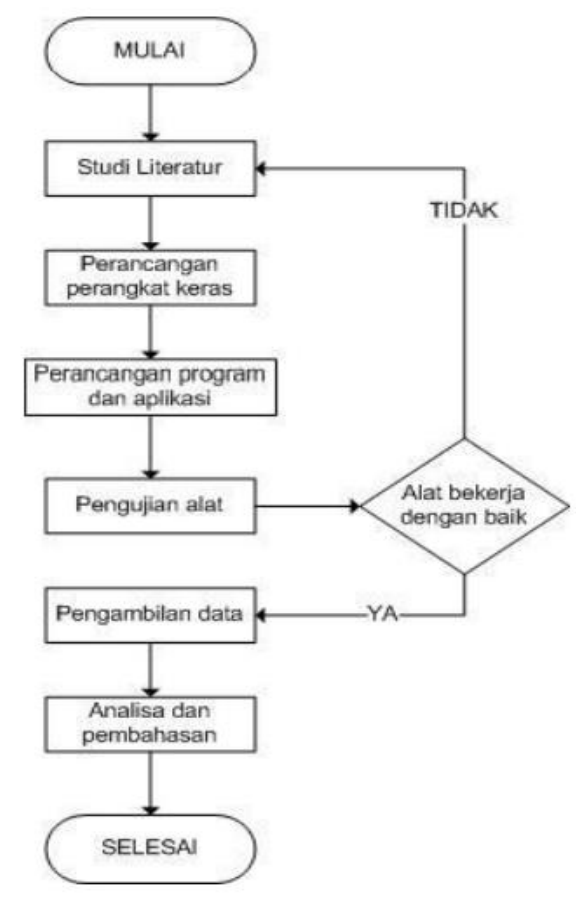

Gbr.10 Diagram Alir Penelitian

\section{Diagram Blok Prototipe}

Sistem prototipe yang dibangun terdiri dari beberapa perangkat elektronika serta sensor yang bekerja agar memudahkan dalam pembacaan dibuatlah diagram blok pada tugas akhir ini.

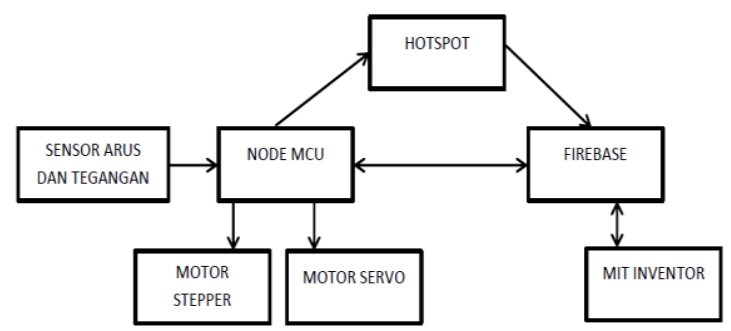

Gbr.11 Diagram Alir Pembuatan Prototipe

Gambar 10 menunjukan blok diagram sistem. Langkah pertama dari sistem kerja dari alat ini yaitu node MCU melakukan koneksi ke hotspot dengan SSID dan password untuk mendapatkan koneksi internet. setelah mendapatkan koneksi internet node MCU mengakses firebase dengan URL dan token dari URL firebase tersebut kemudian Mit inventor mengakses firebase dengan URL dan token tersebut. Kemudian mit inventor mengirimkan perintah ke fire base.

Selanjut nya mit inventor membaca variable arus dan tegangan yang ada di real time database yang ada di fire base. Node MCU membaca real time data base fire base yang berisi variable yang di tentukan untuk memutar motor sehingga motor akan berputar sesuai yang telah di tentukan

\section{Perancangan Program}

Modul Wifi ESP8266 digunakan memiliki library untuk mengintegrasikan degan jaringan internet melalui teknologi Wifi. ESP8266 membutuhkan SSID dan password Wifi untuk terhubung dengan jaringan internet seperti source code berikut ini:

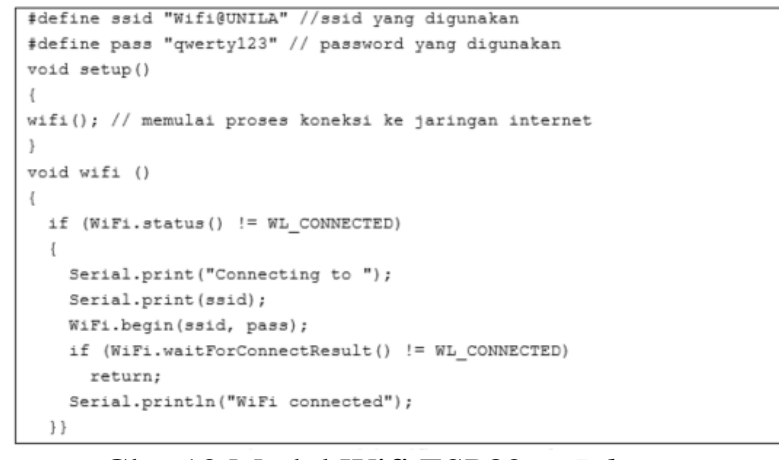

Gbr. 12 Modul Wifi ESP8266 Library

Modul Wifi ESP8266 library pada gambar 15 menjelaskan bahwa ada proses yang dilakukan adalah mengecek terlebih dahulu apakah perangkat sudah terhubung dengan internet. Jika perangkat belum terhubung dengan jaringan internet, maka perangkat akan mencoba menghubungkan dengan jaringan internet sketch Wifi.begin (SSID, password). Setelah sudah bisa terhubung dengan internet maka ESP8266 modul wifi akan muncul tulisan "Wifi Connected".

\section{PENGUJIAN DAN ANALISIS}

\section{A. Prinsip Kerja Prototipe}

Prototipe smart door lock ini dirancang untuk menganalisis pengaruh Arus, Torsi dan Daya motor pada saat diberikan beban yang berbeda-beda, dan juga untuk memberikan inovasi pengguna kunci pada pintu dengan menggunakan aplikasi yang terhubung melalui internet untuk membuka atau 
mengunci pintu. Motor yang digunakan adalah motor dc jenis stepper dengan torsi besar dan motor servo 5v. Mikrokontroler Nodemcu dan driver motor L298N yang digunakan sebagai pengendali pada motor yang digunakan pada prototipe smart kunci pintu ini. Pada alat ini juga di tambahkan dengan sensor arus INA 219 agar dapat memonitoring berapa arus dan tegangan yang digunakan saat alat ini dijalankan.Sebagai pemberi perintah digunakanlah aplikasi yang di install pada handphone android dengan spesifikasi OS minimal gingerbread.

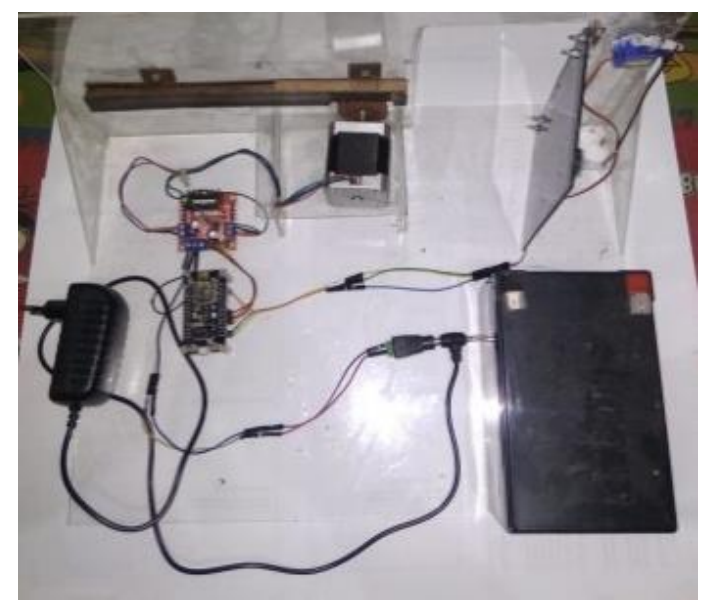

Gbr. 13 Prototipe Smart door lock

Sistem rangkaian sistem keseluruhan dapat dilihat pada Gambar 18. merupakan rangkaian yang menghubungkan seluruh rangkaian elektronika lainnya menjadi satu kesatuan sistem, dalam hal ini pada rangkaian alat yang dibuat terdiri dari beberapa bagian utama diantaranya: power supply, Nodemcu, driver motor stepper, rangkaian relay $5 \mathrm{~V}$. Power supply digunakan untuk memberikan tegangan pada driver motor. Nodemcu berfungsi untuk mengolah data digital dari android dan memberikan trigger pada rangkaikan relay dan driver motor untuk dikirimkan menggunakan komunikasi internet ke firebase. Internet berfungsi sebagai perantara komunikasi Nodemcu dan android, Serta driver motor stepper digunakan sebagai penggerak motor stepper.

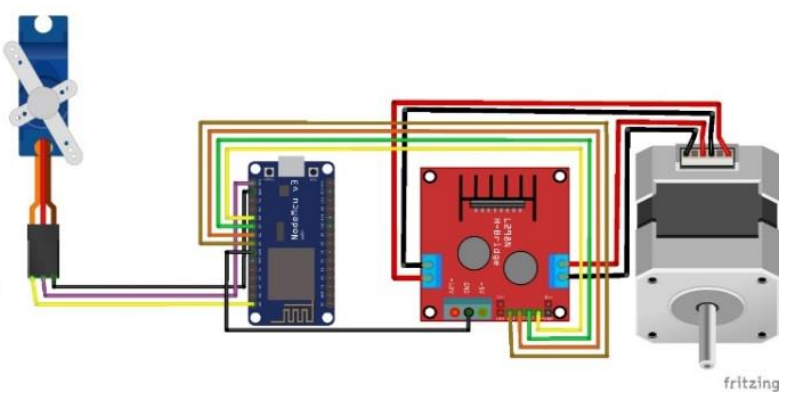

Gbr 14 Rangkaian Sistem Prototipe

Sistem rangkaian prototipe yang telah dibuat sudah melalui proses simulasi dan dalam proses realisasi nya pengukuran dan pengambilan data membutuhkan tingkat error yang rendah sehingga prinsip kerja sistem menghasilkan data yang valid. Rangkaian sistem kerja prototipe dalam pengukuran untuk pengambilan data. Panel surya terpapar oleh sinar matahari secara dinamis dan mengalirkannya pada aki. Keluaran panel surya melewati ACS712 dan sensor tegangan sehingga nilai arus dan tegangan yang mengalir dapat terukur. Hasil pengukuran akan menghasilkan sinyal yang dikirimkan ke arduino. Arduino membutuhkan catu daya tegangan tegangan 5 sampai 12 Volt untuk bekerja, catu daya berasal dari aki. Arduino merupakan pengatur komponen lain untuk bekerja. Arduino mengatur BH1750, DS18B20 Waterproof dan ESP8266 menyimpan data hasil pengukuran pada database. Pada saat kondisi sama LDR akan memberikan sinyal untuk arduino menggerakkan servo secara lateral dan axial.

\section{B. Hasil perancangan aplikasismart door lock}

Aplikasi pada smartphone yang telah dibuat ini berperan dalam memberi perintah ke perangkat keras. Aplikasi ini dibuat menggunakan software App Inventor. Aplikasi ini akan terhubung dengan perangkat keras melalui internet. Perintah dari smartphone berupa data informasi akan diolah oleh nodemcu sebelum dieksekusi. Diagram blok perancangan aplikasi pada smartphone terlihat seperti dibawah ini: 


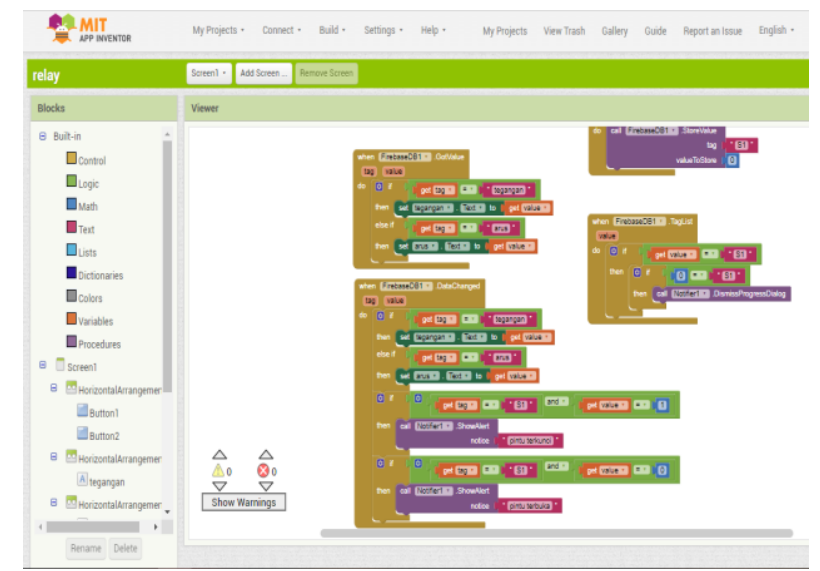

Gbr. 15 Perancangan Aplikasi Smart Dor Lock

\section{Hasil perancangan aplikasi smart door lock}

Pengujian aplikasi smart lock dilakukan dengan menguji proses aktifitas dari tombol kunci pintu dan buka kunci. Terdapat tombol kunci pintu pada aplikasi ini yaitu untuk memberikan triger ke database dari firebase. Pengujian ini dilakukan dengan melihat keberhasilan proses perubahan data pada database. Pada Aplikasi terdapat juga notifikasi status pintu dan juga terdapat monitoring arus dan tegangan yang di gunaklan secara realtime saat alat kita dijalan kan. Berikut adalah tampilan aplikasi Smart dor lock.

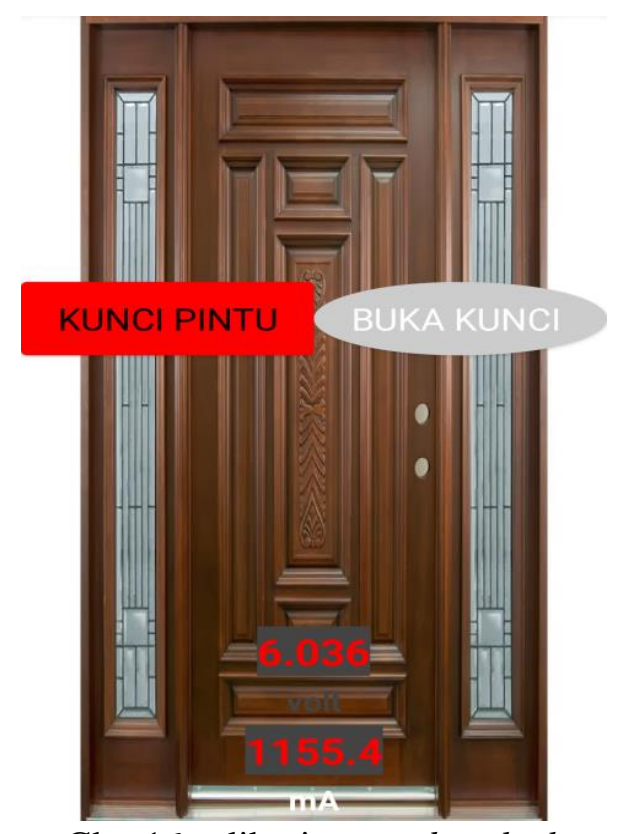

Gbr. 16 aplikasi smart door lock
D. Data hasil

1) Pengujian Aplikasi

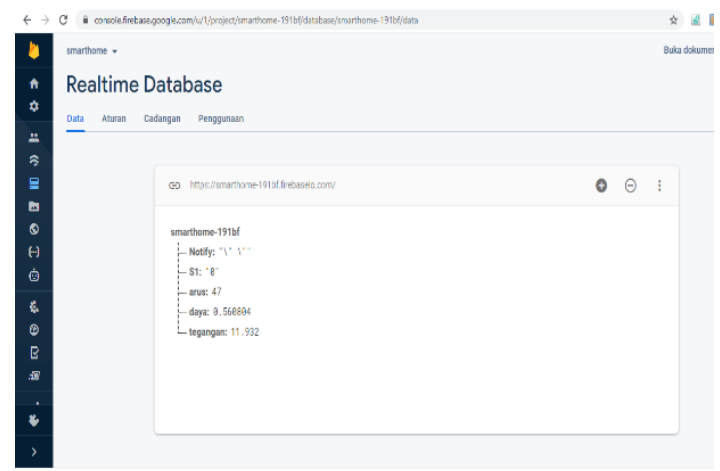

Gbr.17 pengujian aplikasi

2) Pengujian Perangkat Keras

Tujuan dari pengujian ini adalah untuk mengetahui apakah Prototipe Smart Lock Menggunakan Motor Stepper Berbasis Berbasis IOT (Internet Of Things) bekerja baik dan benar.

3) Pengujian beban

Pengujian beban dilakukan sebanyak 3 kali dengan beban yang berbeda beda.

Tabel 4.1 Hasil Pengujian dengan beban 0.080

\begin{tabular}{|c|c|c|}
\hline Pengujian & $\begin{array}{c}\text { Tegangan } \\
(\mathrm{V})\end{array}$ & $\begin{array}{c}\text { Arus Motor } \\
(\mathrm{mA})\end{array}$ \\
\hline Buka Kunci & 6.036 & 1155.4 \\
\hline Kunci Pintu & 6.036 & 1155.4 \\
\hline
\end{tabular}

Dari hasil pengujian didapatkan hasil seperti tabel diatas, dimana pada saat motor membuka kunci dan mengunci pintu dengan tegangan 6.036 volt dan arus sebesar 1.1554A.

Tabel 4.2 Hasil Pengujian dengan beban 0.115

\begin{tabular}{|c|c|c|}
\hline Pengujian & $\begin{array}{c}\text { Tegangan } \\
(\mathrm{V})\end{array}$ & $\begin{array}{c}\text { Arus Motor } \\
(\mathrm{mA})\end{array}$ \\
\hline Buka Kunci & 6.036 & 1265.6 \\
\hline Kunci Pintu & 6.036 & 1265.6 \\
\hline
\end{tabular}

Dari hasil pengujian didapatkan hasil seperti tabel diatas, dimana pada saat motor membuka kunci dan mengunci pintu dengan tegangan 6.036 volt dan arus sebesar 1.2656 A. 
Tabel 4.3 Hasil Pengujian dengan beban 0.170 $\mathrm{kg}$

\begin{tabular}{|c|c|c|}
\hline Pengujian & $\begin{array}{c}\text { Tegangan } \\
(\mathrm{V})\end{array}$ & $\begin{array}{c}\text { Arus Motor } \\
(\mathrm{mA})\end{array}$ \\
\hline Buka Kunci & 6.036 & 1370.2 \\
\hline Kunci Pintu & 6.036 & 1370.2 \\
\hline
\end{tabular}

Dari hasil pengujian didapatkan hasil seperti tabel diatas, dimana pada saat motor membuka kunci dan mengunci pintu dengan tegangan 6.036 volt dan arus sebesar 1.3702 A.

Berikut bentuk grafik hubungan antara Arus terhadap beban pada saat membuka kunci dan mengunci dari data tabel-tabel di atas :

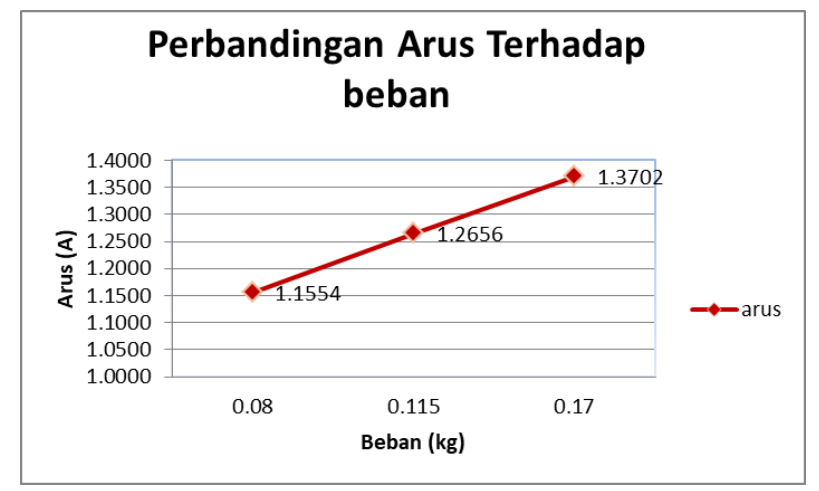

Gbr.18 Grafik perbandingan arus terhadap beban

Dari grafik di atas nilai Arus (A) di tunjukan dengan garis berwarna merah dimana semakin besar beban yang di gunakan saat membuka ataupun mengunci pintu maka semakin beras juga arus yg di gunakan.

Hasil Perhitungan Daya Motor dengan Beban 0,08 kg.

(membuka kunci pintu )

$\mathrm{P}=\mathrm{V}$. I $\quad \mathrm{t}=\mathrm{F}$. $\mathrm{L}$

$\mathrm{P}=(6.036) .(1.1554) \mathrm{t}=(\mathrm{m} . \mathrm{a}) .1$

$\mathrm{P}=6.97$ Watt $\mathrm{t}=(0,08.9,8)(0,06)$

(mengunci pintu )

$$
\mathrm{t}=0,0470 \mathrm{Nm}
$$

$\mathrm{P}=\mathrm{V}$. I $\quad \mathrm{t}=\mathrm{F}$. $\mathrm{L}$

$\mathrm{P}=(6.036) .(1.1554) \quad \mathrm{t}=(\mathrm{m} \cdot \mathrm{a}) .1$

$\mathrm{P}=6.97$ Watt $\mathrm{t}=(0,08.9,8)(0,06)$

$$
\mathrm{t}=0,0470 \mathrm{Nm}
$$

Dari hasil perhitungan di atas, maka dapat disimpulkan bahwa saat percobaan dengan beban $0,080 \mathrm{~kg}$, dibutuhkan daya sebesar 6.97 watt, untuk membuka dan mengunci pintu.
Hasil Perhitungan Daya Motor dengan Beban $0,115 \mathrm{~kg}$

(membuka kunci pintu )

$\mathrm{P}=\mathrm{V}$. I $\quad \mathrm{t}=\mathrm{F}$. $\mathrm{L}$

$\mathrm{P}=(6.036) .(1.2656) \mathrm{t}=(\mathrm{m} . \mathrm{a} 5) .1$

$\mathrm{P}=7.63$ Watt $\mathrm{t}=(0,115.9,8)(0,06)$ $\mathrm{t}=0,06762 \mathrm{Nm}$

(mengunci pintu )

$\mathrm{P}=\mathrm{V}$. I $\quad \mathrm{t}=\mathrm{F}$. L

$P=(6.036) .(1.2656) t=$ (m.a). 1

$\mathrm{P}=7.63$ Watt $\mathrm{t}=(0,115.9,8)(0,06)$ $\mathrm{t}=0,06762 \mathrm{Nm}$

Dari hasil perhitungan di atas, maka dapat disimpulkan bahwa saat percobaan dengan beban $0,115 \mathrm{~kg}$, dibutuhkan daya sebesar 7,63 watt, untuk membuka dan mengunci pintu

Hasil Perhitungan Daya Motor dengan Beban $0,170 \mathrm{~kg}$.

(membuka kunci pintu )

$\mathrm{P}=\mathrm{V}$. I $\quad \mathrm{t}=\mathrm{F}$. L

$\mathrm{P}=$ (6.036).( 1.3702) $\quad \mathrm{t}=$ (m.a).1

$\mathrm{P}=8.27$ Watt $\mathrm{t}=(0,170.9,8)(0,06)$ $\mathrm{t}=0,0999 \mathrm{Nm}$

(membuka kunci pintu )

$\mathrm{P}=\mathrm{V}$. I $\quad \mathrm{t}=\mathrm{F} . \mathrm{L}$

$\mathrm{P}=(6.036) .(1.3702) \quad \mathrm{t}=(\mathrm{m} . \mathrm{a}) .1$

$\mathrm{P}=8.27$ Watt $\quad \mathrm{t}=(0,170.9,8)(0,06)$ $\mathrm{t}=0,0999 \mathrm{Nm}$

Dari hasil perhitungan di atas, maka dapat disimpulkan bahwa saat percobaan dengan beban $0,170 \mathrm{~kg}$, dibutuhkan daya sebesar 8.27 watt, untuk membuka dan mengunci pintu. Berikut bentuk grafik hubungan daya saat membuka dan mengunci terhadap beban :

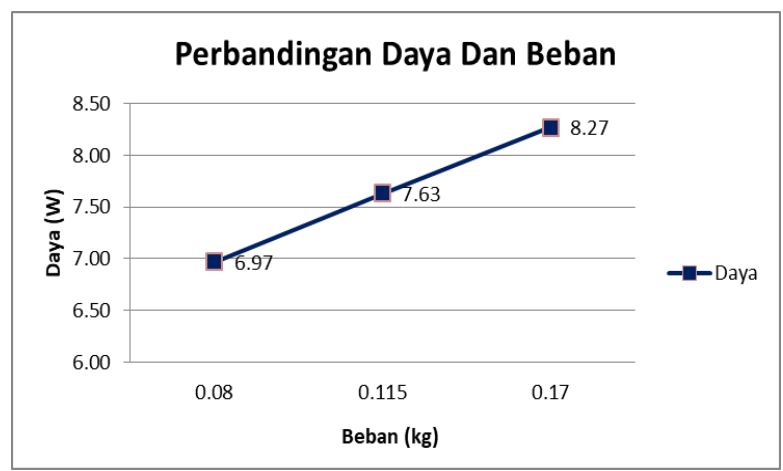

Gbr. 19 Grafik perbandingan Daya terhadap beban

Dari grafik di atas nilai Daya (w) di tunjukan dengan garis berwarna biru dimana 
semakin besar beban yang di gunakan saat membuka ataupun mengunci pintu maka semakin beras juga daya yg di gunakan.

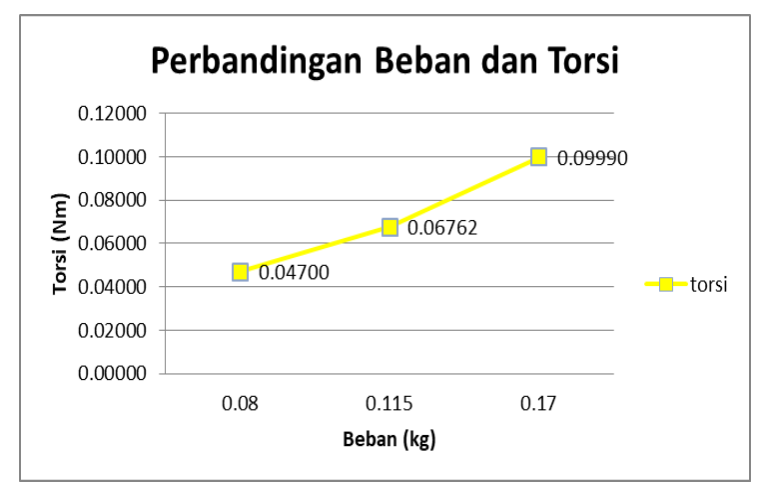

Gbr. 20 Grafik perbandingan Torsi terhadap beban

Dari grafik di atas nilai Torsi $(\mathrm{Nm})$ di tunjukan dengan garis berwarna kuning dimana semakin besar beban yang di gunakan saat membuka ataupun mengunci pintu maka semakin beras juga torsi yang di keluarkan.

Tabel 4.4 Data hasil percobaan keseluruhan

\begin{tabular}{|c|c|c|c|c|c|}
\hline Perintah & $\begin{array}{c}\text { Beban } \\
(\mathbf{K g})\end{array}$ & $\begin{array}{c}\text { Tegangan } \\
(\mathbf{V})\end{array}$ & $\begin{array}{c}\text { Arus } \\
(\mathbf{A})\end{array}$ & $\begin{array}{c}\text { Daya } \\
(\mathbf{W a t})\end{array}$ & $\begin{array}{c}\text { Torsi } \\
(\mathbf{N m})\end{array}$ \\
\hline Buka & \multirow{2}{*}{0,080} & 6.036 & 1.1554 & 6.97 & 0,0470 \\
\hline Tutup & & 6.036 & 1.1554 & 6.97 & 0,0470 \\
\hline Buka & \multirow{2}{*}{0,115} & 6.036 & 1.2656 & 7.63 & 0,06762 \\
\hline Tutup & & 6.036 & 1.2656 & 7.63 & 0,06762 \\
\hline Buka & \multirow{2}{*}{0,170} & 6.036 & 1.3702 & 8.27 & 0,0999 \\
\hline Tutup & & 6.036 & 1.3702 & 8.27 & 0,0999 \\
\hline
\end{tabular}

Dari data tersebut maka dapat disimpulkan tegangan optimal yang digunakan motor pada saat membuka dan mengunci adalah 6.036 $\mathrm{Vdc}$

\section{KESIMPULAN}

1. Prototipe Smart Lock Menggunakan Motor Stepper Berbasis IOT (Internet Of Things) bekerja dengan range waktu selama 4-6 detik.

2. Prototipe ini memiliki jarak jangkauan pengendalian menggunakan smartphone dimana saja selama masih terdapat jaringan internet.

3. Pada pengujian motor stepper tegangan yang diperlukan motor saat membuka kunci sebesar 6.036 Volt dan Volt sehingga untuk start motor memerlukan waktu yang lebih lama.

\section{REFERENSI}

1. Abendroth, B., Kleiner, A. \& Nicholas, P. (2017). Cybersecurity policy for the internet of things. USA: Microsoft Corporation.

2. Arduino.2015."NodeMCU“'.https://www.a rduino.cc/en/Main/Nodemcu

(Diaksespada 10 oktober 2019)

3. Syahrul, Mei 2011, "Motor Stepper: Teknologi, Metoda Dan Rangkaian Kontrol'.UNIKOM.Volume6,No,3,http://j urnal.unikom.ac.id/_s/data/jur nal/v06n02/vol-6-artikel-7.pdf/pdf/vol-6-artikel7.pdf (Diakses pada 16 Maret 2016)

4. Benetta Aranjo, Prashant Kumar Soori, and Puja Talukder, 2012, "Stepper Motor Drives for Robotic Applications “. International Engineering and optimazion Conferrence, 2012

5. "Zerø-Drift, Bi-Directional CURRENT/POWER MONITOR with I2C IM Interface data sheet," Texas Instruments

6. Erma Susanti \& Joko Triyono, "PROTOTYPE ALAT IOT (INTERNET OF THINGS) UNTUK PENGENDALI DAN PEMANTAU KENDARAAN SECARA REALTIME".Simposium Nasional RAPI XV, 2016

7. Arafat "SISTEM PENGAMANAN PINTU RUMAH BERBASIS Internet Of Things (IoT) Dengan ESP8266 “.Technologia, 2016

8. Muhammad Izzuddin Mahali, "SMART DOOR LOCKS BASED ON INTERNET of THINGS CONCEPT WITH MOBILE BACKEND as a SERVICE" .Jurnal Electronics, Informatics, and Vocational Education (ELINVO), Volume 1, Nomor 3, November 2016

9. MUHAMAD IRFAN KURNIAWAN, UNANG SUNARYA, \& ROHMAT TULLOH, "Sistem Keamanan Rumah berbasis Raspberry $\mathrm{Pi}$ dan Telegram Messenger'.ELKOMIKA, 2017

10. Thet Yee Mon, San Hlaing Oo \& Hnin Ei Phyu, "Design and Implementation of Microcontroller Based Stepper Motor Control Sistem for 3-Axis Airfoil Maker CNC Machine "International Journal of 
Scientific and Research Publications,

Volume 8, Issue 9, September 2018

11. S.Vigneshrao, S. Karthik, C.Yuvaraj, "Design Of 3-Axis Computer Numerical Control (CNC) Router Using Stepper Motor". International Journal of Global Engineering (IJGE) E- ISSN: 2456-3099, Maret 2017

12. Benetta Aranjo, Prashant Kumar Soori, and Puja Talukder, 2012, "Stepper Motor Drives for Robotic Applications “. International Engineering and optimazion Conferrence, 2012

\section{Biografi}

Noer soedjarwo menerima gelar Sarjana Teknik dari Universitas, pada tahun. Kemudian menyelesaikan gelar M.T. di pada tahun. Saat ini adalah dosen senior di Universitas Lampung sejak.

Gigih Forda Nama menerima gelar Sarjana Teknik dari Universitas lampung, Indonesia, pada tahun 2007. Menyelesaikan gelar M.T.I. di Universitas indonesia,Indonesia, pada tahun. Saat ini adalah dosen di Universitas Lampung sejak tahun 2008.

Rega Astu Nugroho menerima gelar Sarjana Teknik dari Jurusan Teknik Elektro, Fakultas Teknik, Universitas Lampung pada tahun 2020. 